

Науковий вісник Львівського національного університету ветеринарної медицини та біотехнологій імені С.3. Гжицького

Scientific Messenger of Lviv National University of Veterinary Medicine and Biotechnologies named after S.Z. Gzhytskyj

doi:10.15421/nvlvet7718

ISSN 2518-7554 print

ISSN 2518-1327 online

$\underline{\text { http://nvlvet.com.ua/ }}$

УДК 577.1:636.09.616.99

\title{
Вплив препарату «Трифузол» на функціональний стан печінки у курчат за еймеріозної інвазії
}

\author{
М.О. Криштальська, В.М. Гунчак, Б.В. Гутий \\ bvh@ukr.net
}

Львівський національний університет ветеринарної медицини та біотехнологій імені С.3. Гжицького, вул. Пекарська, 50, м. Львів, 79010, Україна

У процесі життедіяльності протеїни крові курей відіграють важливу фізіологічну роль у складних процесах обміну речовин. Зміни біохімічного складу крові курей за експериментальної інвазії відображають розвиток патологічних та імунних процесів і вказують на стресовий стан організму, щзо дає змогу об 'єктивно оцінити вплив різноманітних факторів на організм інвазованих курчат. Нами встановлено, що у курчат, уражених еймеріозною інвазією, у сироватиі крові був низький рівень загального протеїну і особливо його альбумінової фракиії. Це вказує на пригнічення протеїнсинтезувальної функції печінки. Натомість вміст глобулінів у сироватиі крові хворих курчат був на 12\% вищим. На тлі загальної гіпопротеїнемії встановлено суттєву диспропориію між альбумінами і глобулінами у сироватиі крові хворих курчат, на щзо вказує зменшення величини А/Г коеріиієнта.

Після застосування для лікування курчат, уражених еймеріозною інвазією, препарату «Бровафом» завдяки його протипротозойній дї усувається вплив токсинів на печінку і слизову оболонку кишечнику. Однак протеӥнсинтезувальна функція печінки на 28 добу досліду у дослідних курчат повністю не відновлюється.

При застосуванні препарату «Трифузол» курчатам дослідної групи Дз за еймеріозної інвазії нами встановлено підвищення рівня загального протеїну та альбумінової фракції, а також зниження рівня глобулінів у сироватиі крові курчат протягом усього досліду. На 21 і 28 доби досліджень у курчат дослідної групи спостерігаємо нормалізацію показників протеїнсинтезувальної функиії печінки. У межах фізіологічних величин був також А/Г коефіиієнт.

Сукупне застосування «Бровафому» із «Трифузолом» дослідним курчатам за еймеріозної інвазії сприяло кращій нормалізаиії протеїнсинтезувальної функиї̈ печінки, ніж застосування самого «Бровафому».

Ключові слова: фармакологія, паразитологія, кров, курчата, еймеріозна інвазія, загальний протеїн, альбуміни, глобуліни.

\section{Влияние препарата «Трифузол» на функциональное состояние печени у цыплят при эймериозной инвазии}

\author{
М.А. Криштальская, В.М. Гунчак, Б.В. Гутый \\ bvh@ukr.net
}

\begin{abstract}
Львовский национальный университет ветеринарной медицины и биотехнологий имени С.3. Гжицкого, ул. Пекарская, 50, г. Львов, 79010, Украина
\end{abstract}

В проиессе жизнедеятельности протеины крови кур играют важную физиологическую роль в сложных процессах обмена веществ. Изменение биохимического состава крови кур при экспериментальной инвазии отражают развитие патологических и иммунных процессов и указывают на стрессовое состояние организма, что позволяет объективно оценить влияние различных факторов на организм инвазированных цыплят. Нами установлено, что у цыплят, пораженных эймериозной инвазией, в сыворотке крови был низкий уровень общего белка и особенно его альбуминовой фракиии. Это указывает на подавление протеинсинтезирующей функции печени. Зато содержание глобулинов в сыворотке крови больных иьплят было на $12 \%$ выме. На фоне общей гипопротеинемии установлено существенную диспропориию между альбуминами и глобулинами в сыворотке крови больных ирыплят, на что указывает уменьшение величины А/Г коэффициента.

\section{Citation:}

Kryshtalska, M., Hunchak, V., Gutyj, B. (2017). Influence of the drug «Trifuzol» on the functional state of the liver in chickens for eymeriozic invasion. Scientific Messenger LNUVMBT named after S.Z. Gzhytskyj, 19(77), 76-79. 
После применения для лечения цุыплят, пораженных эймериозной инвазией, препарата «Бровафом» благодаря его противопротозойному действию устраняется влияние токсинов на печень и слизистую оболочку кишечника. Однако протеинсинтезирующая функция печени на 28 сутки опыта в опытных цыылят полностью не восстанавливается.

При применении препарата «Трифузол» иыплятам исследовательской группь при эймериозной инвазии нами установлено повышение уровня общего белка и альбуминовой фракции, а также снижение уровня глобулинов в сыворотке крови иыплят в течение всего опыта. На 21 и 28 сутки исследований у цыплят опытной группь наблюдаем нормализачию показателей протеинсинтезирующей функиии печени. В границах физиологических величин был также А/Г коэффициент.

Совокупное применение «Бровафома» и «Трифузола» исследовательским иыплятам при эймериозной инвазии способствовало лучшей нормализации протеинсинтезирующей функции печени, чем применение самого Бровафома.

Ключевые слова: фармакология, паразитология, кровь, цыплята, эймериозная инвазия, общий протеин, альбумины, глобулины.

\title{
Influence of the drug «Trifuzol» on the functional state of the liver in chickens for eymeriozic invasion
}

\author{
M. Kryshtalska, V. Hunchak, B. Gutyj \\ bvh@ukr.net \\ Lviv National University of Veterinary Medicine and Biotechnologies named after S.Z. Gzhytskyj, \\ Pekarska Str., 50, Lviv, 79010, Ukraine
}

In the process of vital functions chicken blood proteins play an important physiological role in the complex processes of metabolism. Changes in blood biochemical composition of chickens according to experimental invasions reflect the development of pathological and immune processes and point on the stress of the body, which makes it possible objectively evaluate the impact of various factors on the organism of infested chickens. We have found that chickens infected eymeriozic invasion in blood serum was a low level of total protein and especially its albumin fraction. This indicates inhibition of protein synthesized liver function. In return the content of globulin in blood serum of sick chickens was 12\% higher. On the background of the general hypoproteinemia was found a significant disparity between albumin and globulins in blood serum of sick chickens, as indicated by a decrease in the A/T ratio.

After applying for the treatment of chickens affected eymeriozic invasion, drug "Brovafom», due to its antiprotozoic action the influence of toxins eliminates on the liver and intestinal mucosa. However, the protein synthesized function of liver at 28 day of the experiment in experimental chickens has not been completely restored.

In applying the drug «Trifuzol» to chickens from the research group D3, for eymeriozic invasion we have found the level increase in total protein and albumin fractions, and also level lowering of globulin in serum of chickens throughout the experiment. At the 21 st and 28 th day of research in chickens from the experimental group we observe the indices normalization of protein synthesized function of the liver. Within physiological variables was also A/T ratio.

Combined use of Brovafom and Trifuzol to experimental chickens for eymeriozic invasion, contributed to better normalization in protein synthesized of liver function, than the use of Brovafom.

Key words: pharmacology, parasitology, blood, chickens, eymeriozic invasion, total protein, albumin, globulin.

\section{Вступ}

Птахівництво - одна 3 найбільш інтенсивних галузей сільськогосподарського виробництва. Біологічні особливості курей дають можливість порівняно швидко отримувати м'ясну та яєчну продукцію, що обумовлює iї високу рентабельність та окупність. Проте розвиток птахівництва стримують паразитарні хвороби, які набули широкого розповсюдження і завдають значних економічних збитків спеціалізованим, фермерським та присадибним господарствам. Особливого значення набувають питання всебічного вивчення інвазійних захворювань (Iljushechkin, 1992; Verzhykhovskyi et al., 2007; Berezovskyi, 2007; Hariv et al., 2016).

Однією з перешкод, що гальмує розвиток птахівництва, є еймеріозна інвазія у молодняку птиці до 23-місячного віку, яка проявляється пригніченням, проносами, часто з домішками крові, схудненням (Sandul, 2003). Загибель птиці може сягати 50-70\% від кількості хворих; несучість починається на 1-2 місяці пізніше та значно нижча порівняно 3 несучістю здорової птиці. Джерелом інвазії $є$ хворі курчата, а також доросла птиця, яка часто є носієм збудників інвазії (Khariv et al., 2015).
Вивчення змін рівня протеїну та його фракцій у сироватці крові, взаємопов'язаних із продуктивністю курей при еймеріозній інвазії, має важливе значення. Відомо, що загальний протеїн відіграє важливу роль у різноманітних життєвих процесах. Пояснюється це головним чином природою білків, які лежать в основі різноманітних фізіологічних функцій тваринного організму, їх різними специфічними фізико-хімічними та біологічними властивостями й особливою пластичністю (Khariv et al., 2016). Вони беруть активну участь у побудові ферментних і гормональних систем організму, а тому будь-які зміни вмісту та співвідношення білків у крові впливають на весь організм.

Метою нашої роботи було вивчити вплив препарату «Трифузол» на функціональний стан печінки у курчат за експериментальної еймеріозної інвазії.

\section{Матеріали і методи досліджень}

Для вирішення поставлених завдань було сформовано дві дослідні групи курей: контрольну та дослідну за принципом аналогів, враховуючи масу тіла та фізіологічний стан. Кожна група складалася 3 восьми курейнесучок віком 4 тижні на початок експерименту. 
Курей дослідних груп заражали суспензією інвазійних ооцист у кількості 50000 на курку. Кури контрольної групи (інтактні) виступали контролем.

Курчата першої дослідної групи були уражені еймеріозною інвазією. Курчат другої дослідної групи ліку- вали препаратом «Бровафом». Курчата третьої дослідної групи отримували препарат «Бровафом» та «Трифузол» (табл. 1).

Досліди на курчатах

Таблиця 1

\begin{tabular}{|c|l|}
\hline Групи курчат & \multicolumn{1}{|c|}{ Схема дослідів } \\
\hline К & Курчата знаходились на стандартному раціоні (інтактні) \\
\hline$Д_{1}$ & Курчат заражали суспензією інвазійних ооцист у кількості 50000 на курча \\
\hline$Д_{2}$ & $\begin{array}{l}\text { Курчат заражали суспензією інвазійних ооцист у кількості } 50000 \text { на курча та лікували «Бровафомом» у } \\
\text { дозі 3 г/кг корму }\end{array}$ \\
\hline$Д_{3}$ & $\begin{array}{l}\text { Курчат заражали суспензією інвазійних ооцист у кількості } 50000 \text { на курча та лікували «Бровафомом» у } \\
\text { дозі 3 г/кг корму і «Трифузолом» у дозі 2 мл на 1 л води }\end{array}$ \\
\hline
\end{tabular}

Матеріалом для біохімічних досліджень слугували відібрані проби крові із vena axilaris на 7, 14, 21 та 28 доби після зараження. Відбір проб крові проводили 3 дотриманням усіх правил асептики та антисептики.

У сироватці крові досліджували: рівень загального протеїну біуретовою пробою, а вміст окремих його фракцій - турбідиметричним методом за Л.М. Делекторською (Delektorskaja et al., 1971).

\section{Результати та їх обговорення}

Аналіз отриманих даних вказує, що кров курчат за експериментальної інвазії згідно з біохімічними показниками суттєво відрізняється від крові контрольних курчат (табл. 1). Так, аналіз досліджень вказує на зниження обміну білка в організмі курчат за рахунок зменшення вмісту загального протеїну. Так, на 7 добу досліду вміст загального протеїну у сироватці крові дослідної групи курчат знизився на 9\% відносно контрольної групи. На 14 і 21 доби досліду спостерігали вірогідне зниження досліджуваного показника відповідно на 18 і
$22 \%$. Найнижчим вміст загального протеїну у сироватці крові дослідних курчат спостерігали на 28 добу досліду, де відповідно він становив 2,3 $\pm 0,11$ г\%.

Вміст альбумінів у крові контрольної групи курчат коливався у межах 42,5 $\pm 2,25-43,1 \pm 2,15 \%$. Після зараження курчат ооцистами еймерій протягом усіх діб експерименту в крові курчат дослідної групи було встановлено тенденцію до зменшення вмісту альбумінів, проте вірогідне зниження встановлено лише на 21 і 28 доби експерименту. Так, у вказані періоди досліджень вміст альбумінів коливався у межах $36,6 \pm 2,19-$ $35,9 \pm 2,21 \%$. Зниження альбумінів у сироватці крові дослідної групи курчат пояснюється порушенням синтетичних процесів альбуміну в печінці та вказує на більш інтенсивне використання білків цієї фракції як пластичного матеріалу.

Отже, у курчат уражених еймеріозною інвазією, пригнічується синтез альбумінів у печінці внаслідок дії токсичних метаболітів на гепатоцити.

Вміст білка і його фракцій у сироватці крові курчат, уражених еймеріозною інвазією (M \pm m; n=8)

\begin{tabular}{|c|c|c|c|c|c|}
\hline \multirow{2}{*}{$\begin{array}{c}\text { Дослідні } \\
\text { групи }\end{array}$} & \multirow{2}{*}{ До зараження } & \multicolumn{4}{|c|}{ Доби дослідження після зараження дослідних курчат } \\
\hline & & 7 & 14 & 21 & 28 \\
\hline \multicolumn{6}{|c|}{ Загальний протеїн, г\% } \\
\hline $\mathrm{K}$ & $3,1 \pm 0,24$ & $3,1 \pm 0,39$ & $3,3 \pm 0,20$ & $3,2 \pm 0,22$ & $3,3 \pm 0,18$ \\
\hline$Д_{1}$ & $3,2 \pm 0,18$ & $2,8 \pm 0,11$ & $2,6 \pm 0,13$ & $2,4 \pm 0,10^{*}$ & $2,3 \pm 0,11^{*}$ \\
\hline$Д_{2}$ & $3,1 \pm 0,20$ & $2,9 \pm 0,13$ & $2,8 \pm 0,11$ & $2,7 \pm 0,12$ & $2,9 \pm 0,15$ \\
\hline$Д_{3}$ & $3,2 \pm 0,21$ & $3,0 \pm 0,20$ & $3,1 \pm 0,22$ & $3,3 \pm 0,19$ & $3,4 \pm 0,15$ \\
\hline \multicolumn{6}{|c|}{ Альбуміни, \% } \\
\hline K & $42,5 \pm 2,25$ & $42,8 \pm 2,41$ & $43,1 \pm 2,15$ & $42,7 \pm 2,17$ & $43,0 \pm 2,20$ \\
\hline Д $_{1}$ & $42,2 \pm 2,20$ & $41,1 \pm 2,24$ & $38,5 \pm 2,16$ & $36,6 \pm 2,19 *$ & $35,9 \pm 2,21^{*}$ \\
\hline$Д_{2}$ & $42,3 \pm 2,24$ & $41,8 \pm 2,32$ & $40,9 \pm 2,30$ & $40,2 \pm 2,15$ & $39,5 \pm 2,20$ \\
\hline$Д_{3}$ & $42,1 \pm 2,20$ & $42,2 \pm 2,20$ & $42,9 \pm 2,20$ & $42,5 \pm 1,90$ & $43,2 \pm 2,10$ \\
\hline \multicolumn{6}{|c|}{ Глобуліни, \% } \\
\hline K & $57,5 \pm 3,20$ & $57,2 \pm 3,18$ & $56,9 \pm 3,25$ & $57,3 \pm 3,15$ & $57,0 \pm 3,14$ \\
\hline$Д_{1}$ & $57,8 \pm 3,15$ & $58,9 \pm 3,20$ & $61,5 \pm 3,23$ & $63,4 \pm 3,32 *$ & $64,1 \pm 3,42^{*}$ \\
\hline$Д_{2}$ & $57,7 \pm 2,85$ & $58,2 \pm 3,22$ & $59,1 \pm 3,17$ & $59,8 \pm 3,30$ & $60,5 \pm 3,31$ \\
\hline$Д_{3}$ & $57,9 \pm 3,10$ & $57,8 \pm 3,15$ & $57,1 \pm 3,19$ & $57,5 \pm 3,24$ & $56,8 \pm 3,25$ \\
\hline \multicolumn{6}{|c|}{ Коефіцієнт А/Г, \% } \\
\hline K & 0,74 & 0,75 & 0,76 & 0,75 & 0,75 \\
\hline Д $_{1}$ & 0,73 & 0,70 & 0,63 & 0,58 & 0,56 \\
\hline Д $_{2}$ & 0,73 & 0,72 & 0,69 & 0,67 & 0,65 \\
\hline$д_{3}$ & 0,73 & 0,73 & 0,75 & 0,74 & 0,76 \\
\hline
\end{tabular}

Примітка: ступінь вірогідності $*-\mathrm{P}<0,05$ 
Рівень глобулінів у сироватці крові курчат контрольної і дослідних груп на початку досліду був у межах $57,5 \pm 3,20-57,8 \pm 3,15 \%$. У першої дослідної групи курчат після зараження ооцистами еймерій у сироватці крові, встановлено підвищення рівня глобулінів. На 7 добу експерименту рівень глобулінів у сироватці крові курчат дослідної групи Д зріс на $3 \%$, тимчасом як на 14 добу - відповідно на 8\% відносно контролю. У подальшому рівень глобулінів продовжував зростати і на 28 добу експерименту відповідно становив $64,1 \pm 3,42 \%$.

Збільшення глобулінів в сироватці крові інвазованих курчат відбувалося за рахунок подразнення токсинами паразитів і продуктами розпаду білка системи мононуклеарних фагоцитів. Підвищення рівня глобулінів у сироватці крові відображає інтенсивність запальних процесів слизової оболонки кишечнику курчат.

Зміни в білкових фракціях між дослідною першою і контрольною групами курчат призвели до різниці А/Г коефіцієнта. У курчат дослідної групи величина А/Г коефіцієнта була нижчою на 7, 17, 23 і 25\% від контрольної групи курчат відповідно на 7-, 14-, 21- та 28-у доби досліду. Така величина коефіцієнта безсумнівно вказує на пригнічення протеїнсинтезувальної функції печінки.

Після застосування хворим курчатам «Бровафому» у дозі 3 кг/т корму, рівень загального протеїну у крові хворих курчат почав зростати, так на 14 добу досліду рівень загального протеїну зріс на 8\%, на 21 добу досліду відповідно зріс на 12,5\% відносно показників крові курчат групи Д. . На 28 добу досліду рівень загального протеїну в сироватці крові курчат дослідної групи Д2 зростав, однак порівняно 3 величинами контрольної групи курчат він був дещо нижчим. Визначення у сироватці крові хворих і лікованих курчат лише вмісту загального протеїну, без визначення рівня альбумінів, не дає об'єктивної оцінки протеїнсинтезувальної функції печінки. Важливим показником функціонального стану печінки є величина альбуміно-глобулінового коефіцієнта (А/Г коефіцієнт). Чим він менший від оптимального, тим у більшій мірі зменшена протеїнсинтезувальна функція печінки. При дослідженні рівня альбумінів у сироватці крові курчат дослідної групи Д 2 встановлено, що на 21 і 28 добу досліду він був вищим на 10\% відносно показників крові курчат групи Д . При дослідженні рівня глобулінів встановлено зниження їх рівня, де порівняно $з$ першою дослідною групою він знизився на 6\%. А/Г коефіцієнт у дослідної групи Д 2 хоч зростав, однак за контроль був нижчим.

Отримані результати досліджень вказують на те, що у курчат, уражених еймеріозною інвазією, за лікування «Бровафомом» не повністю відновилася протеїнсинтезувальна функція печінки. На це вказує низький рівень альбумінів та наявні запальні процеси, що підтверджує підвищений рівень глобулінів.

При застосуванні препарату «Трифузол» курчатам дослідної групи Дз за еймеріозної інвазії нами встановлено підвищення рівня загального протеїну та альбумінової фракції, а також зниження рівня глобулінів у сироватці крові курчат протягом усього досліду. На 21 i 28 доби досліджень у курчат третьої дослідної групи спостерігаємо нормалізацію показників протеїнсинте- зувальної функції печінки. У межах фізіологічних величин був також А/Г коефіцієнт.

\section{Висновки}

1. Зміни білкового обміну служать важливим об'єктивним показником стану організму курей як у нормі, так і в патології. Склад протеїну і протеїнових фракцій характеризують ступінь резистентності організму (Khariv et al., 2016).

2. За експериментальної інвазії курчат спостерігали зміни біохімічних показників крові, що супроводжувалися гіпопротеїнемією, гіпоальбумінемією та гіперглобулінемією.

3. Після застосування для лікування курчат, уражених еймеріозною інвазією, препарату «Бровафом», завдяки його протипротозойній дії усувається вплив токсинів на печінку і слизову оболонку кишечнику. Однак, протеїнсинтезувальна функція печінки на 28 добу досліду в дослідних курчат повністю не відновлюється;

4. Сукупне застосування «Бровафому» із «Трифузолом» дослідним курчатам за еймеріозної інвазії сприяло кращій нормалізації протеїнсинтезувальної функції печінки, ніж застосування самого «Бровафому».

\section{Бібліографічні посилання}

Berezovskyi, A.V. (2007) Invaziini khvoroby sviiskoi ptytsi. Navchalnyi posibnyk. K.: Vetinform (in Ukrainian).

Delektorskaja, L.M. Sentebaeva, N.A., Saluznaja, A.M. (1971). Ob unifikacii metodov opredelenija obshhego belka $\mathrm{v}$ syrovatke krovi. Lab. delo. 8, 483-487 (in Russian).

Hariv, I.I., Gutyj, B.V., Gufrij, D.F., Vishhur, O.I., Hariv, M.I., Guta, Z.A (2016). Vlijanie amprolinsila i brovitakokcida na sostojanie immunnoj sistemy indeek pri jejmerioznoj invazii. Nauchno-prakticheskij zhurnal. Uchenye Zapiski. Vitebsk. 52(2), 24-28 (in Russian).

Khariv, M.I., Gutyj, B.V., Vishchur, O.I., Solovodzinska, I.Ye. (2016). Funktsionalnyi stan pechinky u shchuriv za umov oksydatsiinoho stresu ta dii liposomalnoho preparatu. Nauk. zap. Ternop. nats. ped. un-tu. Ser. Biol. 2(66), 76-84 (in Ukrainian).

Khariv, I.I., Gutyj, B.V., Butsiak, V.I., Venhryn, A.V. (2015). Vyvchennia kumuliatyvnykh vlastyvostei «Amprolinsylu». Naukovyi visnyk Lvivskoho natsionalnoho universytetu veterynarnoi medytsyny ta biotekhnolohii im. Gzhytskoho. 17, 1(1), 208-213 (in Ukrainian).

Verzhykhovskyi, O., Kolos, Yu.,Tytarenko, V., Stets, V. (2007). Epizootychnyi stan ptakhivnytstva v Ukraini. Veterynarna medytsyna Ukrainy. 6, 8-10 (in Ukrainian).

Iljushechkin, Ju.P. (1992). Kokcidiozy v promyshlennom pticevodstve. Pticevodstvo. 1, 22-23 (in Russian).

Sandul, A.V. (2003). Problema jejmerioza v brojlernom pticevodstve. Issledovanija molodyh uchenih $\mathrm{v}$ reshenii problem zhivotnovodstva: mater. III Mezhdunarodnoj nauch.-praktich. konf. Vitebsk, 204-205 (in Russian).

Стаття надійшла до редакиії 11.03.2017 